\title{
Ulvibacter litoralis gen. nov., sp. nov., a novel member of the family Flavobacteriaceae isolated from the green alga Ulva fenestrata
}

Correspondence

Olga I. Nedashkovskaya olganedashkovska@piboc.dvo.ru or olganedashkovska@yahoo.com
Olga I. Nedashkovskaya, ${ }^{1}$ Seung Bum Kim, ${ }^{2}$ Suk Kyun Han, ${ }^{2}$

Moon Soo Rhee, ${ }^{2}$ Anatoly M. Lysenko, ${ }^{3}$ Enevold Falsen, ${ }^{4}$

Galina M. Frolova, ${ }^{1}$ Valery V. Mikhailov ${ }^{1}$ and Kyung Sook Bae ${ }^{2}$

\begin{abstract}
${ }^{1}$ Pacific Institute of Bioorganic Chemistry of the Far-Eastern Branch of the Russian Academy of Sciences, Pr. 100 Let Vladivostoku 159, 690022, Vladivostok, Russia

${ }^{2}$ Korean Collection for Type Cultures, Biological Resources Center, Korea Research Institute of Bioscience and Biotechnology, Yusong, Daejon 305-333, Republic of Korea

${ }^{3}$ Institute of Microbiology of the Russian Academy of Sciences, Pr. 60 Let October 7/2, Moscow, 117811, Russia

${ }^{4}$ Culture Collection, Department of Clinical Bacteriology, University of Göteborg, Guldhedsgatan 10, S-413 46 Göteborg, Sweden
\end{abstract}

Two heterotrophic, aerobic, Gram-negative, pigmented and non-motile marine bacteria that were isolated from the green alga Ulva fenestrata were studied by polyphasic taxonomic methods.

$16 \mathrm{~S}$ rDNA sequence analysis indicated that strain $\mathrm{KMM} 3912^{\top}$ formed a distinct lineage within the family Flavobacteriaceae. On the basis of phenotypic, chemotaxonomic, genotypic and phylogenetic analyses, the novel bacteria were classified as Ulvibacter litoralis gen. nov., sp. nov.

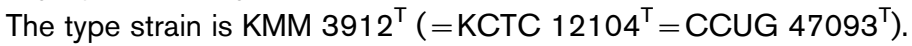

Pigmented bacteria that belong to the phylum CytophagaFlavobacterium-Bacteroides (CFB) are one of the dominant groups of the many microbial populations that inhabit different marine environments (Glöckner et al., 1999; Bano \& Hollibaugh, 2002; Kirchman, 2002). Despite broad application of molecular techniques to bacterial identification, study of the phenotypic properties of micro-organisms is essential for species discrimination (Vandamme et al., 1996). For example, the presence of cell-bound flexirubintype pigments is considered to be an important phenotypic characteristic for differentiation of the bacteria of the CFB phylum from each other and from other Gram-negative, non-motile micro-organisms (Fautz \& Reichenbach, 1980). Six species of marine representatives of the CFB phylum, namely Chryseobacterium indoltheticum, Chryseobacterium

Published online ahead of print on 4 July 2003 as DOI 10.1099/ ijs.0.02757-0.

Abbreviations: CCUG, Culture Collection University of Göteborg, Göteborg, Sweden; CFB, Cytophaga-Flavobacterium-Bacteroides group; KCTC, Korean Collection for Type Cultures, Korea Research Institute of Bioscience and Biotechnology, Daejon, Republic of Korea; KMM, Collection of Marine Microorganisms of the Pacific Institute of Bioorganic Chemistry of the Far-Eastern Branch of the Russian Academy of Sciences, Vladivostok, Russia.

The GenBank/EMBL/DDBJ accession number for the 16S rRNA gene sequence of Ulvibacter litoralis KMM $3912^{\top}$ is AY243096. scophthalmum, Zobellia galactanivorans, Zobellia uliginosa, Reichenbachia agariperforans and Vitellibacter vladivostokensis, are currently known to be flexirubin-type pigment producers; they demonstrate a colony colour shift from yellow or orange to red, brown or purple after addition of $20 \% \mathrm{KOH}$ (Reichenbach, 1989; Vandamme et al., 1994; Barbeyron et al., 2001; Nedashkovskaya et al., 2003a, b). During the investigation of taxonomic diversity of the microbial population of the common green alga Ulva fenestrata from the Sea of Japan, novel flexirubin-producing bacteria were isolated. Phylogenetic analysis based on $16 \mathrm{~S}$ rDNA sequencing revealed that strain KMM 3912 ${ }^{\mathrm{T}}$ forms a cluster with representatives of the genera Cellulophaga, Arenibacter, Zobellia, Muricauda, Aequorivita and Vitellibacter and with [Cytophaga] marinoflava, in which it occupies a distinct lineage.

The polyphasic taxonomic study presented in this work, which includes characterization of the phenotypic, chemotaxonomic and genotypic characteristics of strains KMM $3912^{\mathrm{T}}$ and KMM 3976 in combination with phylogenetic differences, supports the creation of a novel genus; we therefore describe a novel member of the family Flavobacteriaceae, designated Ulvibacter litoralis gen. nov., sp. nov.

Strains KMM $3912^{\mathrm{T}}$ and KMM 3976 were isolated from samples of the green alga Ulva fenestrata that were collected 
in Troitsa Bay, Gulf of Peter the Great, Sea of Japan, during June 2000. For strain isolation, $0 \cdot 1 \mathrm{ml}$ homogenates of algal fronds were transferred onto plates of marine agar 2216 (Difco). After primary isolation and purification, strains were cultivated at $28{ }^{\circ} \mathrm{C}$ on the same medium and stored at $-80{ }^{\circ} \mathrm{C}$ in marine broth (Difco) supplemented with $20 \%$ $(\mathrm{v} / \mathrm{v})$ glycerol.

Oxidative or fermentative utilization of glucose was determined by using the medium of Hugh \& Leifson, modified for marine bacteria (Lemos et al., 1985). Catalase activity was tested by addition of $3 \%(\mathrm{v} / \mathrm{v}) \mathrm{H}_{2} \mathrm{O}_{2}$ solution to a bacterial colony and observation for the appearance of gas. Flexirubin pigments were detected by using the method of Fautz \& Reichenbach (1980). Gram-staining reaction, degradation of alginic acids $(1 \%, \mathrm{w} / \mathrm{v})$ and agar $(1.5 \%, \mathrm{w} / \mathrm{v})$, oxidase, urease, alkaline phosphatase and $\beta$-galactosidase activities, production of acid from carbohydrates, hydrolysis of starch, casein, gelatin, cellulose (filter paper and CMcellulose), chitin, Tweens 20,40 and 80 and DNA, nitrate reduction and production of hydrogen sulphide and indole were carried out according to methods described by Smibert \& Krieg (1994). To examine carbon source utilization, commercial API 20NE identification strips (bioMérieux) were used, following the instructions of the manufacturers, with a medium that contained $0.2 \mathrm{~g} \mathrm{NaNO}_{3}, 0.2 \mathrm{~g} \mathrm{NH}_{4} \mathrm{Cl}$, $0.05 \mathrm{~g}$ yeast extract (Difco) and $0.4 \%(\mathrm{w} / \mathrm{v})$ carbon source in $1000 \mathrm{ml}$ artificial sea water. In order to study the temperature range for growth, bacteria were cultivated on medium $\mathrm{A}$, which consisted of $\left(\mathrm{l}^{-1}\right): 5 \mathrm{~g}$ Bacto peptone (Difco), $2 \mathrm{~g}$ Bacto yeast extract (Difco), $1 \mathrm{~g}$ glucose, $0.02 \mathrm{~g}$ $\mathrm{KH}_{2} \mathrm{PO}_{4}$ and $0.05 \mathrm{~g} \mathrm{MgSO}_{4} .7 \mathrm{H}_{2} \mathrm{O}$ in $50 \%(\mathrm{v} / \mathrm{v})$ natural sea water and $50 \%(\mathrm{v} / \mathrm{v})$ distilled water. Bacterial growth at different concentrations of $\mathrm{NaCl}$ was checked on medium $\mathrm{A}$ that was prepared with distilled water and contained $0,1,2$, $3,5,6,8,10$ or $12 \%(\mathrm{w} / \mathrm{v}) \mathrm{NaCl}$. Spreading growth was observed by cultivation on medium $\mathrm{B}$, which contained $\left(1^{-1}\right): 1 \mathrm{~g}$ Bacto peptone (Difco), $1 \mathrm{~g}$ yeast extract (Difco), $15 \mathrm{~g}$ agar and half-strength natural sea water under conditions of high moisture. Gliding motility was determined as described by Bowman (2000). Cell movement at colony edges was verified by using phase-contrast microscopy. Susceptibility to antibiotics was examined by the routine diffusion plate method. Discs were impregnated with the following antibiotics: ampicillin $(10 \mu \mathrm{g})$, benzylpenicillin $(10 \mu \mathrm{g})$, carbenicillin $(100 \mu \mathrm{g})$, gentamicin $(10 \mu \mathrm{g})$, kanamycin $(30 \mu \mathrm{g})$, lincomycin $(15 \mu \mathrm{g})$, neomycin $(30 \mu \mathrm{g})$, oleandomycin $(15 \mu \mathrm{g})$, polymyxin B (300 U), streptomycin $(10 \mu \mathrm{g})$ and tetracycline $(30 \mu \mathrm{g})$.

The organisms isolated in this study were Gram-negative, chemo-organotrophic with respiratory-type metabolism, non-motile, single, flexible rods that were $0 \cdot 4-0.5 \mu \mathrm{m}$ in diameter and $2 \cdot 5-7 \cdot 3 \mu \mathrm{m}$ in length. Optimal growth was observed at $1 \cdot 5-2 \% \mathrm{NaCl}$. Temperature range for growth was $4-34^{\circ} \mathrm{C}$ for KMM $3912^{\mathrm{T}}$ and $4-36^{\circ} \mathrm{C}$ for KMM 3976 , with optimum growth occurring at $21-23^{\circ} \mathrm{C}$. pH range for growth was $5 \cdot 5-10 \cdot 0$, with optimum growth occurring between $\mathrm{pH} 7 \cdot 1$ and $8 \cdot 3$. Both strains were susceptible to carbenicillin and lincomycin and strain $\mathrm{KMM} 3912^{\mathrm{T}}$ was also susceptible to oleandomycin and tetracycline. Other physiological and biochemical findings are listed in Table 1 and the species description.

Analysis of fatty acid methyl esters was carried out according to the standard protocol of the Microbial Identification system (Microbial ID). Cellular fatty acids of KMM $3912^{\mathrm{T}}$ were as follows: $\mathrm{i}-\mathrm{C}_{14: 0}(1.9 \%), \mathrm{i}-\mathrm{C}_{15: 0}(21 \cdot 3 \%)$, a- $\mathrm{C}_{15: 0}$ $(2 \cdot 3 \%), \mathrm{i}-\mathrm{C}_{15: 1}(12 \cdot 5 \%), \mathrm{C}_{15: 0}(3 \cdot 9 \%), \mathrm{C}_{15: 1} \omega 6 c(1 \cdot 2 \%)$, i-C $\mathrm{C}_{16: 0}(2 \cdot 8 \%), \mathrm{i}-\mathrm{C}_{16: 1}(4 \cdot 2 \%), \mathrm{C}_{16: 1} \omega 7 / \mathrm{i}-\mathrm{C}_{15: 0} 2-\mathrm{OH}$ $(5 \cdot 7 \%), \mathrm{i}-\mathrm{C}_{17: 1} \omega 9 c(3 \cdot 7 \%), \mathrm{C}_{17: 1} \omega 6 c(1 \cdot 5 \%), \mathrm{C}_{15: 0} 2-\mathrm{OH}$ $(1 \cdot 2 \%), \mathrm{i}-\mathrm{C}_{15: 0} 3-\mathrm{OH}(3 \cdot 3 \%), \mathrm{C}_{15: 0} 3-\mathrm{OH}(1 \cdot 3 \%), \mathrm{i}-\mathrm{C}_{16: 0}$ $3-\mathrm{OH}(8 \cdot 7 \%), \mathrm{i}_{1} \mathrm{C}_{17: 0} 3-\mathrm{OH}(17 \cdot 2 \%), \mathrm{C}_{17: 0} 2-\mathrm{OH}(1 \cdot 7 \%)$ and unidentified fatty acids $(3 \cdot 2 \%)$. The predominant fatty acids were straight- and branched-chain unsaturated, namely, $\mathrm{i}-\mathrm{C}_{15: 0}, \mathrm{i}-\mathrm{C}_{15: 1}, \mathrm{i}-\mathrm{C}_{16: 0} 3-\mathrm{OH}$ and $\mathrm{i}-\mathrm{C}_{17: 0} 3-\mathrm{OH}$, which represented $59 \cdot 7 \%$ of the total fatty acids. It should be noted that the whole-cell fatty acid profile of strain KMM $3912^{\mathrm{T}}$ was characterized by the presence of $79 \cdot 3 \%$ branched fatty acids. These results are consistent with data reported for other representatives of the family Flavobacteriaceae (Bruns et al., 2001; Nedashkovskaya et al., 2003b). Isoprenoid quinones were extracted from lyophilized cells and analysed as described by Akagawa-Matsushita et al. (1992). Isoprenoid quinone composition was characterized by HPLC (Shimadzu), using a reverse-phase type Zorbax ODS column $(250 \times 4 \cdot 6 \mathrm{~mm})$ and acetonitrile/propan-2-ol $(65: 35, \mathrm{v} / \mathrm{v})$ as the mobile phase at a flow rate of $0.5 \mathrm{ml} \mathrm{min}{ }^{-1}$. The column was kept at $40{ }^{\circ} \mathrm{C}$. Menaquinones were detected by monitoring $A_{270}$ and were identified by comparison with known quinones from reference strain Salegentibacter salegens DSM $5424^{\mathrm{T}}$. The main lipoquinone was MK-6.

DNA was isolated following the method of Marmur (1961) and its $\mathrm{G}+\mathrm{C}$ content was determined by the thermal denaturation method (Marmur \& Doty, 1962). DNA-DNA hybridization was performed spectrophotometrically and initial renaturation rates were recorded as described by De Ley et al. (1970). The DNA G + C content was 36.7$38.0 \mathrm{~mol} \%$ as determined by the thermal denaturation method. DNA-DNA relatedness between KMM $3912^{\mathrm{T}}$ and KMM 3976 was $85 \%$.

DNA extraction, PCR and sequencing of $16 \mathrm{~S}$ rDNA followed previous procedures (Kim et al., 1998). The obtained sequence data were aligned with those of representative members of selected genera of the family Flavobacteriaceae by using PHYDIT version 3.2 (http://plaza.snu.ac.kr/ jchun/phydit/). Phylogenetic trees were inferred by using suitable programs of the PHYLIP package (Felsenstein, 1993). Phylogenetic distances were calculated from the models of Kimura (1980) and trees were constructed on the basis of the neighbourjoining (Saitou \& Nei, 1987), least-squares (Fitch \& Margoliash, 1967) and maximum-likelihood (Felsenstein, 1993) algorithms. Bootstrap analysis was performed with 1000 resampled datasets by using the SEQBOOT and CONSENSE programs of the PHYLIP package. 
Table 1. Differential characteristics of Ulvibacter litoralis and allied genera of the family Flavobacteriaceae

Species/taxon: 1, Ulvibacter litoralis; 2, Cellulophaga; 3, [Cytophaga] marinoflava; 4, Aequorivita; 5, Arenibacter; 6, Zobellia; 7, Muricauda; 8, Vitellibacter. Data from Reichenbach (1989), Johansen et al. (1999), Bowman (2000), Barbeyron et al. (2001), Bruns et al. (2001), Ivanova et al. (2001), Bowman \& Nichols (2002), Nedashkovskaya et al. (2003b, c) and this study. Abbreviations: -, negative; +, positive; V, variable; ND, not determined.

\begin{tabular}{|c|c|c|c|c|c|c|c|c|}
\hline Characteristic & 1 & 2 & 3 & 4 & 5 & 6 & 7 & 8 \\
\hline Gliding motility & + & + & + & - & - & + & + & - \\
\hline Flexirubin pigments & + & - & - & - & - & + & - & + \\
\hline Requirement for $\mathrm{Na}^{+}$for growth & + & + & - & $\mathrm{V}$ & + & + & + & + \\
\hline Acid formation from carbohydrates & - & + & + & - & + & + & ND & - \\
\hline $37^{\circ} \mathrm{C}$ & - & $\mathrm{V}$ & - & - & + & + & + & + \\
\hline $42{ }^{\circ} \mathrm{C}$ & - & - & - & - & + & + & - & + \\
\hline \multicolumn{9}{|l|}{ Hydrolysis of: } \\
\hline Agar & - & + & - & - & - & + & - & - \\
\hline Casein & - & $\mathrm{V}$ & - & $\mathrm{V}$ & - & + & $\mathrm{ND}$ & + \\
\hline Nitrate reduction & + & $\mathrm{V}$ & + & - & + & + & - & - \\
\hline $\mathrm{H}_{2} \mathrm{~S}$ production & - & - & - & - & $\mathrm{V}$ & - & - & - \\
\hline DNA G $+\mathrm{C}$ content $(\mathrm{mol} \%)$ & $36-38$ & $33-38$ & 37 & $33-39$ & $37-40$ & $42-43$ & 41 & 41 \\
\hline
\end{tabular}

Phylogenetic analysis of almost-complete $16 \mathrm{~S}$ rDNA sequence (1385 nucleotide positions) revealed that strain KMM $3912^{\mathrm{T}}$ forms a distinct lineage in a cluster that includes members of the family Flavobacteriaceae (Bernardet et al., 2002), such as Cellulophaga, Arenibacter, Zobellia, Muricauda, Aequorivita, Vitellibacter and [Cytophaga] marinoflava (Fig. 1). 16S rDNA sequence similarity values of strain KMM $3912^{\mathrm{T}}$ to its closest relatives, Cellulophaga lytica, Cellulophaga fucicola and [Cytophaga] marinoflava, were $92 \cdot 2,92 \cdot 1$ and $91 \cdot 7 \%$, respectively. The low sequence similarity levels of the strain tested to other members of the CFB phylum that have been described to date $(86 \cdot 2-91 \cdot 5 \%)$ clearly demonstrate that the bacteria isolated in this study represent a novel genus. Results of phenotypic analysis, including production of flexirubin pigments and inability to oxidize carbohydrates or hydrolyse starch, in combination with phylogenetic distinctiveness, allow the differentiation of strains KMM $3912^{\mathrm{T}}$ and KMM 3976 from their nearest neighbours, including Cellulophaga lytica, Cellulophaga fucicola and [Cytophaga] marinoflava. Phenotypic features that separate the strains studied from other members of the family Flavobacteriaceae are shown in Table 1.

The results of the polyphasic analysis presented in this work demonstrate that the bacteria studied could not be assigned to any currently described taxon of the family Flavobacteriaceae and support the placement of strains KMM $3912^{\mathrm{T}}$ and KMM 3976 in a novel genus, Ulvibacter gen. nov., as Ulvibacter litoralis sp. nov.

\section{Description of Ulvibacter gen. nov.}

Ulvibacter (Ul.vi.bac'ter. N.L. fem. n. Ulva generic name of the green alga Ulva fenestrata; N.L. masc. n. bacter from Gr. n. bakterion rod; N.L. masc. n. Ulvibacter rod isolated from the green alga Ulva fenestrata).

Rod-shaped, non-motile cells. Gram-negative. Endospores are not formed. $\mathrm{Na}^{+}$ions are required for growth. Strictly aerobic. Non-diffusible, yellow-orange pigments are produced. Flexirubins are formed. Chemo-organotrophic. Cytochrome oxidase-, catalase- and alkaline phosphatasepositive. Major respiratory quinone is MK-6. Main cellular fatty acids are the straight- and branched-chain unsaturated fatty acids $\mathrm{i}-\mathrm{C}_{15: 0}, \mathrm{i}-\mathrm{C}_{15: 1}, \mathrm{i}-\mathrm{C}_{16: 0} 3-\mathrm{OH}$ and $\mathrm{i}-\mathrm{C}_{17: 0} 3-\mathrm{OH}$. As determined by $16 \mathrm{~S}$ rDNA sequence analysis, the genus Ulvibacter is a member of the family Flavobacteriaceae within the phylum Cytophaga-Flavobacterium-Bacteroides. The type species is Ulvibacter litoralis.

\section{Description of Ulvibacter litoralis sp. nov.}

Ulvibacter litoralis (li.to.ra'lis. L. masc. adj. litoralis of the shore, a shallow-water dweller).

Main characteristics are as given for the genus. In addition, cells range from 0.4 to $0.5 \mu \mathrm{m}$ in width and from 2.5 to $7 \cdot 3 \mu \mathrm{m}$ in length. On marine agar, colonies are $2-4 \mathrm{~mm}$ in diameter, circular, convex, shiny with entire edges, viscous and yellow-orange in colour. Growth is observed at $4-36{ }^{\circ} \mathrm{C}$. 


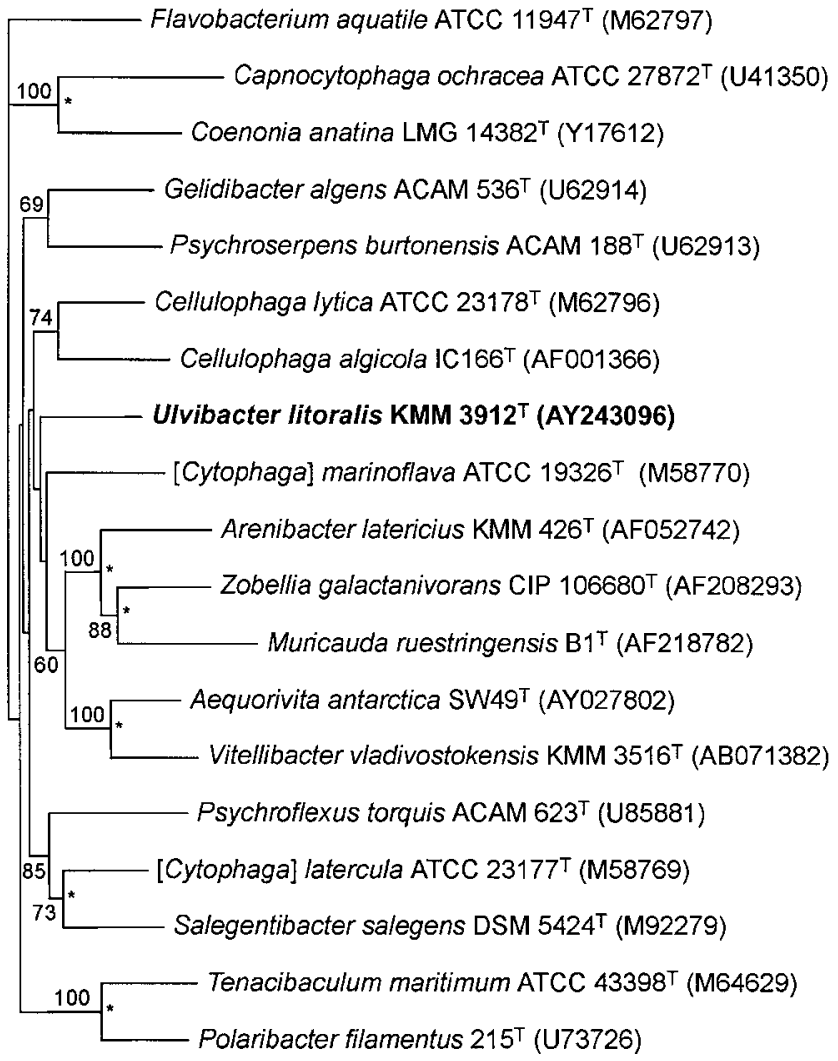

0.01

Fig. 1. Phylogenetic tree based on $16 \mathrm{~S}$ rDNA sequences of strain $\mathrm{KMM} 3912^{\top}$ and representative members of related genera in the family Flavobacteriaceae. The tree was generated by the neighbour-joining method (Saitou \& Nei, 1987). Numbers at nodes indicate bootstrap values (\%) and asterisks indicate branches that were also recovered in Fitch-Margoliash and maximum-likelihood trees. Bar, 0.01 substitutions per nucleotide position.

Optimal temperature for growth is $21-23^{\circ} \mathrm{C}$. Growth occurs at $1-6 \% \mathrm{NaCl}$. Gelatin, Tweens 20 and 40 and DNA are decomposed. Agar, casein, alginate, starch, Tween 80, cellulose (CM-cellulose and filter paper) and chitin are not hydrolysed. No acid is formed from cellobiose, fucose, galactose, melibiose, raffinose, rhamnose, xylose, adonitol, dulcitol or glycerol. Arabinose, glucose, lactose, mannose, maltose, sucrose, mannitol, inositol, sorbitol, malonate, citrate, $\mathrm{N}$-acetylglucosamine, gluconate, caprate, adipate, malate and phenylacetate are not utilized. Nitrate is reduced. Production of indole, $\mathrm{H}_{2} \mathrm{~S}$ and acetoin (Voges-Proskauer reaction) is negative. DNA $\mathrm{G}+\mathrm{C}$ content is $36 \cdot 7-$ $38 \cdot 0 \mathrm{~mol} \%$.

Type strain is KMM $3912^{\mathrm{T}}$ (= KCTC $12104^{\mathrm{T}}=\mathrm{CCUG}$ $47093^{\mathrm{T}}$ ). Reference strain is KMM 3976. Isolated from the green alga Ulva fenestrata.

\section{Acknowledgements}

This research was supported by grant no. 95-02/03-19 from the Ministry for Industry and Science of the Russian Federation (MIS RF), the Biodiversity Programme of the Russian Academy of Science and MIS RF and grant no. 02-04-49517 from the Russian Foundation for Basic Research. K.S. B., S. K.H. and S. B. K. are also grateful for support from the Korea Research Council of Fundamental Science and Technology (grant no. KBM1000212).

\section{References}

Akagawa-Matsushita, M., Itoh, T., Katayama, Y., Kuraishi, H. \& Yamasato, K. (1992). Isoprenoid quinone composition of some marine Alteromonas, Marinomonas, Deleya, Pseudomonas and Shewanella species. J Gen Microbiol 138, 2275-2281.

Bano, N. \& Hollibaugh, J. T. (2002). Phylogenetic composition of bacterioplankton assemblages from the Arctic Ocean. Appl Environ Microbiol 68, 505-518.

Barbeyron, T., L'Haridon, S., Corre, E., Kloareg, B. \& Potin, P. (2001). Zobellia galactanovorans gen. nov., sp. nov., a marine species of Flavobacteriaceae isolated from a red alga, and classification of [Cytophaga] uliginosa (ZoBell and Upham 1944) Reichenbach 1989 as Zobellia uliginosa gen. nov., comb. nov. Int J Syst Evol Microbiol 51, 985-997.

Bernardet, J.-F., Nakagawa, Y. \& Holmes, B. (2002). Proposed minimal standards for describing new taxa of the family Flavobacteriaceae and emended description of the family. Int J Syst Evol Microbiol 52, 1049-1070.

Bowman, J. P. (2000). Description of Cellulophaga algicola sp. nov., isolated from the surfaces of Antarctic algae, and reclassification of Cytophaga uliginosa (ZoBell and Upham 1944) Reichenbach 1989 as Cellulophaga uliginosa comb. nov. Int J Syst Evol Microbiol 50, 1861-1868.

Bowman, J. P. \& Nichols, D. S. (2002). Aequorivita gen. nov., a member of the family Flavobacteriaceae isolated from terrestrial and marine Antarctic habitats. Int J Syst Evol Microbiol 52, 1533-1541.

Bruns, A., Rohde, M. \& Berthe-Corti, L. (2001). Muricauda ruestringensis gen. nov., sp. nov., a facultatively anaerobic, appendaged bacterium from German North Sea intertidal sediment. Int J Syst Evol Microbiol 51, 1997-2006.

De Ley, J., Cattoir, H. \& Reynaerts, A. (1970). The quantitative measurement of DNA hybridization from renaturation rates. Eur $J$ Biochem 12, 133-142.

Fautz, E. \& Reichenbach, H. (1980). A simple test for flexirubin-type pigments. FEMS Microbiol Lett 8, 87-91.

Felsenstein, J. (1993). PHYLIP (phylogeny inference package), version 3.5c. Department of Genetics, University of Washington, Seattle, USA.

Fitch, W. M. \& Margoliash, E. (1967). Construction of phylogenetic trees. Science 155, 279-284.

Glöckner, F. O., Fuchs, B. M. \& Amann, R. (1999). Bacterioplankton compositions of lakes and oceans: a first comparison based on fluorescence in situ hybridization. Appl Environ Microbiol 65, 3721-3726.

Ivanova, E. P., Nedashkovskaya, O. I., Chun, J. \& 7 other authors (2001). Arenibacter gen. nov., new genus of the family Flavobacteriaceae and description of a new species, Arenibacter latericius sp. nov. Int J Syst Evol Microbiol 51, 1987-1995.

Johansen, J. E., Nielsen, P. \& Sjøholm, C. (1999). Description of Cellulophaga baltica gen. nov., sp. nov. and Cellulophaga fucicola gen. nov., sp. nov. and reclassification of [Cytophaga] lytica to Cellulophaga lytica gen. nov., comb. nov. Int J Syst Bacteriol 49, 1231-1240. 
Kim, S. B., Falconer, C., Williams, E. \& Goodfellow, M. (1998). Streptomyces thermocarboxydovorans $\mathrm{sp}$. nov. and Streptomyces thermocarboxydus sp. nov., two moderately thermophilic carboxydotrophic species from soil. Int J Syst Bacteriol 48, 59-68.

Kimura, M. (1980). A simple method for estimating evolutionary rates of base substitutions through comparative studies of nucleotide sequences. J Mol Evol 16, 111-120.

Kirchman, D. L. (2002). The ecology of Cytophaga-Flavobacteria in aquatic environments. FEMS Microbiol Ecol 39, 91-100.

Lemos, M. L., Toranzo, A. E. \& Barja, J. L. (1985). Modified medium for oxidation-fermentation test in the identification of marine bacteria. Appl Environ Microbiol 40, 1541-1543.

Marmur, J. (1961). A procedure for the isolation of deoxyribonucleic acid from microorganisms. J Mol Biol 3, 208-218.

Marmur, J. \& Doty, P. (1962). Determination of the base composition of deoxyribonucleic acid from its thermal denaturation temperature. J Mol Biol 5, 109-118.

Nedashkovskaya, O. I., Suzuki, M., Vysotskii, M. V. \& Mikhailov, V. V. (2003a). Reichenbachia agariperforans gen. nov., sp. nov., a novel marine bacterium in the phylum Cytophaga-FlavobacteriumBacteroides. Int J Syst Evol Microbiol 53, 81-85.

Nedashkovskaya, O. I., Suzuki, M., Vysotskii, M. V. \& Mikhailov, V. V. (2003b). Vitellibacter vladivostokensis gen. nov., sp. nov., a new member of the phylum Cytophaga-Flavobacterium-Bacteroides. Int J Syst Evol Microbiol 53, 1281-1286.

Nedashkovskaya, O. I., Suzuki, M., Vysotskii, M. V. \& Mikhailov, V. V. (2003c). Arenibacter troitsensis sp. nov., isolated from marine bottom sediment. Int J Syst Evol Microbiol 53, 1287-1290.

Reichenbach, H. (1989). Cytophagales Leadbetter 1974, $99^{A L}$. In Bergey's Manual of Systematic Bacteriology, vol. 3, pp. 2011-2050. Edited by J. T. Staley, M. P. Bryant, N. Pfennig \& J. G. Holt. Baltimore: Williams \& Wilkins.

Saitou, N. \& Nei, M. (1987). The neighbor-joining method: a new method for reconstructing phylogenetic trees. Mol Biol Evol 4, 406-425.

Smibert, R. M. \& Krieg, N. R. (1994). Phenotypic characterization. In Methods for General and Molecular Bacteriology, pp. 607-655. Edited by P. Gerhardt, R. G. E. Murray, W. A. Wood \& N. R. Krieg. Washington, DC: American Society for Microbiology.

Vandamme, P., Bernardet, J.-F., Segers, P., Kersters, K. \& Holmes, B. (1994). New perspectives in the classification of the flavobacteria: description of Chryseobacterium gen. nov., Bergeyella gen. nov., and Empedobacter nom. rev. Int J Syst Bacteriol 44, 827-831.

Vandamme, P., Pot, B., Gillis, M., de Vos, P., Kersters, K. \& Swings, J. (1996). Polyphasic taxonomy, a consensus approach to bacterial systematics. Microbiol Rev 60, 407-438. 